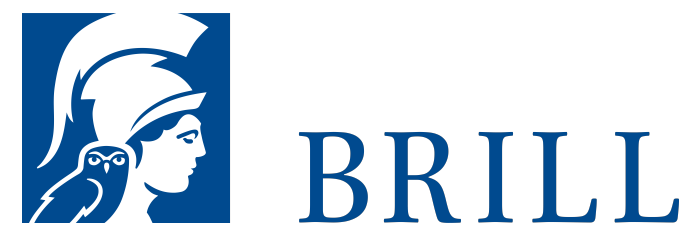

\title{
Hundred-Gated Thebes
}

Acts of a Symposium on Thebes and the Theban Area in the Graeco-Roman Period

Authors: P.W. Pestman and Vleeming

The choachytes (or morticians) of the ancient Egyptian city of Thebes provided a rich documentation linking the city of the living on one side of the Nile with the city of the dead on the other. The family archives of these choachytes deal to a large part with their professional role in serving the dead entrusted to their care, but they are also virtually our only source of information about the city of Thebes, whose physical remains were ruthlessly obliterated in the nineteenth century. This material constitute one end of a chain which links the temple statues of Amun's servants and descriptions of their houses on the one hand with their tombs and their tomb inventories on the other, allowing us to identify individual choachytes from their papers. The papyrological finds can thus provide an exact dating for objects that might otherwise be only dated to within several centuries, while the objects themselves and the tomb architecture provide a factual dimension to historical and legal documents which might otherwise remain flat and arid. It was in order to draw attention to the richness of all the constituent parts of this documentation that a number of scholars were invited to present their views on Graeco-Roman Thebes at a colloqium held from 9 to 11 September 1992 in Leiden, the Netherlands. The survey papers and communications presented at this colloqium are published here.

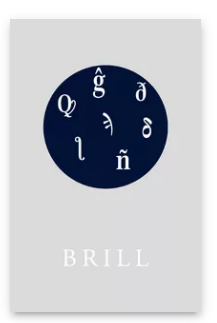

Pages: xiii, 273 pp. illus.

Language:

English

Subjects:

General,

Classical

Studies,

Codicology,

Papyrology \&

Philology,

Ancient Near

East and Egypt

Publisher: Brill

Series:

Papyrologica

Lugduno-

Batava, Volume:

27

E-Book (PDF)

Released online:

28 Apr 2020

ISBN: 978-90-

04-42781-5

List price

USD $\$ 161.00$

Hardback

Publication date:

o1 Jun 1995

ISBN: 978-90-

o4-10384-9 
For more information see brill.com

Order information: Order online at brill.com +44330 333 0049 | customerservices@brill.com Submission information: brill.com/authors

Titles published by Brill | Fink, Brill | mentis or Brill | Schöningh: +49(o)715413279216| brill@brocom.de 